\title{
Characterization of the Replication Terminus of the Bacillus subtilis Chromosome
}

\author{
By MERVYN J. MONTEIRO, MICHAEL G. SARGENT* AND \\ PATRICK J. PIGGOT \\ National Institute for Medical Research, Mill Hill, London NW7 1AA, UK
}

(Received 23 January 1984; revised 19 March 1984)

\begin{abstract}
DNA in the terminal region of the chromosome of Bacillus subtilis was labelled by a procedure in which cells in sporulation inducing conditions were pulse-labelled with $\left[{ }^{3} \mathrm{H}\right]$ thymidine and then treated with $p$-hydroxyphenylazouracil, an inhibitor of DNA synthesis. The labelled DNA in isolated spores yielded a small number of restriction fragments. About 14 EcoRI fragments with a total length of $80 \mathrm{~kb}$ were labelled in a $2.5 \mathrm{~min}$ pulse. A fragment of $4.0 \mathrm{~kb}$ had the highest specific radioactivity in terminally labelled DNA from several strains. One of these strains lacked the $120 \mathrm{~kb}$ prophage of SP $\beta$ that is normally integrated close to the terminus. Loss of the $120 \mathrm{~kb}$ prophage did not affect the point of termination which must therefore be regarded as a specific 'stop' sequence. Labelled terminus DNA has been used to identify lambda (Charon 4A) clones containing sequences derived from the terminal region. The total length of the restriction fragments present was $150 \mathrm{~kb}$ and adds another $90 \mathrm{~kb}$ to the $150 \mathrm{~kb}$ region mapped previously. Only one group of these sequences was present in a B. subtilis strain (CU1695) carrying a deletion spanning from SP $\beta$ to the right of the terminus and gltA. This suggests that the terminator sequence found in the wild-type can be deleted but presumably this strain has an alternative mechanism of termination.
\end{abstract}

\section{INTRODUCTION}

The genetic evidence now available from Escherichia coli and Bacillus subtilis suggests that replication of the circular chromosome proceeds bidirectionally from the origin to a site approximately opposite to the origin. There is evidence from $E$. coli and $B$. subtilis that this is not merely the point at which replication forks meet but is a sequence which arrests replication forks (Kuempel et al., 1977; Louarn et al., 1977; O'Sullivan \& Anagnostopoulos, 1982; Weiss et al., 1982). The biochemical basis of this phenomenon is unknown. Termination sequences have been identified with considerable accuracy in certain plasmids (Germino \& Bastia, 1981). In both organisms, the terminus region is deficient in genetic markers, and contains no markers which define essential functions. The region surrounding the terminus may have important interactions with the cell surface which determine sites of cell division, although the membrane binding site found at $i l v A-i l v D$ is a substantial distance from the terminus (Sargent \& Bennett, 1982). The region may also contain sequences that are substrates for DNA-topoisomerases that dissipate topological constraints generated during replication (Davern, 1979). These are speculations that can be substantiated only after a physical investigation of the region and the isolation of the relevant parts.

The structure of the terminal region of $E$. coli and $B$. subtilis can now be studied at the level of restriction fragments. A $400 \mathrm{~kb}$ restriction map of the terminal region of $E$. coli has been constructed using DNA of a temperature-sensitive mutant, pulse-labelled under its restrictive conditions (Bouché, 1982; Bouché et al., 1982). On this map, the point of termination lies within a $50 \mathrm{~kb}$ region. Using a method devised for $B$. subtilis that is not applicable to $E$. coli, the point of termination can be determined more precisely. Cells of $\boldsymbol{B}$. subtilis in a sporulation-inducing 
medium were provided with $\left[{ }^{3} \mathrm{H}\right]$ thymidine for a short period followed by an inhibitor of DNA synthesis (such as $p$-hydroxyphenylazouracil) which prevents sporulation in cells that have not completed their chromosomes. Labelled spores were thus obtained only from those cells whose chromosomes were completed during the pulse period, and were therefore labelled only in the terminus (Sargent 1980a, $c$; Adams \& Wake, 1980). The labelled DNA yields a small number of fragments on digestion with restriction enzymes (Sargent \& Monteiro, 1982; Weiss et al. 1981), and is indeed replicated last during subsequent cycles of replication (Adams \& Wake, 1980). Weiss \& Wake (1983) have now compiled a $150 \mathrm{~kb}$ restriction map of the $B$. subtilis terminus using DNA labelled by this procedure. They have shown that one arm of the chromosome reaches the terminus about $5 \mathrm{~min}$ before the other; an observation which indicates that the terminus acts as a specific 'stop' sequence. In this report we present a study of terminus-labelled material in several strains of $B$. subtilis, and of cloned terminal fragments which confirm and extend the conclusions of Weiss \& Wake (1983).

\section{METHODS}

Bacteria. The bacteria used for these studies were B. subtilis $168 \operatorname{trp} C 2\left(\mathrm{SP} \beta^{+}\right)$(referred to as $\left.\mathrm{SB} \beta^{+}\right), 168 \operatorname{trp} C 2$ thy A thy $B$ (Callister \& Wake, 1974) (referred to as Thy ${ }^{-}$), CU1050 SP $\beta^{\star}$ sup-3 met B5 thr-5 leuA8 pur A16 (Warner et al., 1977) (referred to as SP $\left.\beta^{-}\right)$, CU1695 trpC2 $\triangle(\mathrm{SP} \beta$ kauA citK gltB gltA) (Zahler, 1982).

Induction of sporulation and labelling of the terminus region. Conditions for induction of sporulation and for terminus labelling were described previously (Sargent, 1980a).

The pattern of restriction fragments labelled was determined by fluorography (Lasky, 1980) using DNA isolated from spores (Sargent, 1980c).

Identification of Charon $4 A$ clones containing DNA from the terminus region. One thousand individual plaques from the Charon 4A bank of Ferrari et al. (1981) were arranged in a three-dimensional matrix with axes $x, y$, and $z$, numbered 0-9. For each point on the $x$ axis, all the phage in the other two dimensions were pooled (i.e. 100 clones). The procedure was repeated for the $y$ and $z$ axes, giving 30 pools. After amplification (deWet $e t$ al., 1980), the phage DNA was prepared and used for hybridization and transformation experiments.

Cloned DNA to be probed with either ${ }^{3} \mathrm{H}$-terminus or ${ }^{32} \mathrm{P}$-nick-translated DNA was denatured and bound to nitrocellulose filters which were then soaked in prehybridization medium (Sargent et al., 1983). In typical hybridization experiments, ${ }^{3} \mathrm{H}$-labelled DNA preparations contained approximately $10^{5} \mathrm{c}$.p.m. spore DNA labelled for $10 \mathrm{~min}$ (specific activity approximately $10^{3}-10^{4} \mathrm{c} . \mathrm{p} . \mathrm{m} \cdot \mathrm{g}^{-1}$ ) and were incubated with filters for $5 \mathrm{~d}$. Approximately $5 \times 10^{5}$ c.p.m. ${ }^{32}$ P-nick-translated probes (Jeffreys \& Flavell, 1977) were incubated with filters for $24 \mathrm{~h} .{ }^{32} \mathrm{P}$ and ${ }^{3} \mathrm{H}$ probes were denatured by boiling in neutral buffer or $0.5 \mathrm{M}$-sodium hydroxide, respectively (Sargent $1980 b$; Sargent et al., 1983). Filters were washed (Sargent et al., 1983), and the radioactivity bound to the filters was determined by liquid scintillation counting. Positive pools were identified as having substantially greater radioactivity than blanks. The co-ordinates of positive clones present in the three-dimensional matrix were given by the pool numbers in the $x, y$ or $z$ series which gave substantial signals. Thus if positive responses were obtained in $3 x, 7 y$ and $2 z$, this would indicate that clone number 372 was positive. Stocks of each phage were prepared starting from single plaques. Hybridization properties were then confirmed using purified phage DNA.

Some clones described were isolated by plaque hybridization (Benton \& Davis, 1977).

Phage handling, DNA isolation and restriction analysis. Single plaques were used to prepare $10 \mathrm{ml}$ primary lysates of the Charon 4A host, DP50 supF. These were used to prepare secondary lysates with titres of $10^{11}-10^{12} \mathrm{ml}^{-1}$ (deWet et al., 1980). Phage were purified with $\mathrm{CsCl}$, and their DNA was isolated after phenol treatment (Sargent $e t$ al., 1983). Restriction fragments to be used as probes were isolated from gels by electrophoresis onto DEAEcellulose (Dretzen et al., 1981). The elution buffer used was $0.2 \mathrm{M}$-Tris/HCl, $\mathrm{pH} 9.0,1.5 \mathrm{M}$-sodium chloride, $1 \%$ (v/v) sarkosyl, 0.05 M-EDTA.

Genetic methods. The presence of genetic markers in recombinant phage was determined using DNA mediated transformation (Sargent \& Bennett, 1982). The following strains were used: MS146 purA16 hisA1 metB5 gltA292 ilvAl trpC2 phe A12 (Sargent \& Bennett, 1982); QB9432 trpC2 ilvA1 thyAl thyB1 gln-9 (Reysset, 1981); CU281 citB $\operatorname{trpC2}$ (supplied by S. A. Zahler); CU1323 gltA2 citKI kauA1 metB5 (Rosenthal et al., 1979); UTB600 gltB1 leuA8 metB10 (Deshpande \& Kane, 1980).

Determination of the time of replication of the $\phi 715$ and $S P \beta$ region. Samples $(10 \mathrm{ml})$ of a sporulating culture of 168 $\operatorname{trpC2}$ were pulse-labelled at various time intervals (Fig. 5) with $\left[{ }^{3} \mathrm{H}\right]$ thymidine $[50 \mu \mathrm{Ci}(1.85 \mathrm{MBq})$ per sample]. Labelling was terminated in all cultures with $p$-hydroxyphenylazouracil $\left(50 \mu \mathrm{g} \mathrm{ml}^{-1}\right) 2 \mathrm{~h}$ after $T_{0}$ (Sargent, $1980 a$ ). Spores were isolated $16 \mathrm{~h}$ later and purified. The radioactivity per $10^{8}$ spores was determined using a Coulter counter to count the spores, and the DNA was then extracted and purified (Sargent, 1980b). DNA hybridization and subsequent washing steps were carried out as described by Sargent $e t$ al. (1983). Exactly $1 \mu \mathrm{g}$ denatured DNA in $0.5 \mathrm{ml}$ of hybridization buffer was incubated with each filter. The filters were loaded with $4 \mu \mathrm{g}$ denatured DNA of $\phi 715$ and $S P \beta$. 


\section{RESULTS}

$\left[{ }^{3} \mathrm{H}\right]$ Thymidine-labelled DNA synthesized during the terminus labelling protocol described above yielded a small number of restriction fragments. The patterns observed by fluorography (Fig. 1) were highly reproducible and there were considerable similarities between different strains (Fig. 1, Table 1 and 2). Thus in a $2.5 \mathrm{~min}$ pulse, at least 11 clearly defined restriction fragments were visible in fluorographs of EcoRI digests of DNA from the three strains. The strains examined included the parental B. subtilis strain (168 trpC2), a Thy $^{-}$derivative thought to contain non-isogenic regions in the terminus (Callister \& Wake, 1974) and a strain (CU1050) (Warner et al., 1977) that had lost the $120 \mathrm{~kb}$ prophage that is present in the terminus region of most 168 strains.

The last fragment to replicate in the chromosome can be labelled at any time during the pulse period and thus will have the highest specific activity. The proximity of other fragments to the terminus is given by their specific radioactivity relative to the hottest fragment. To calculate the

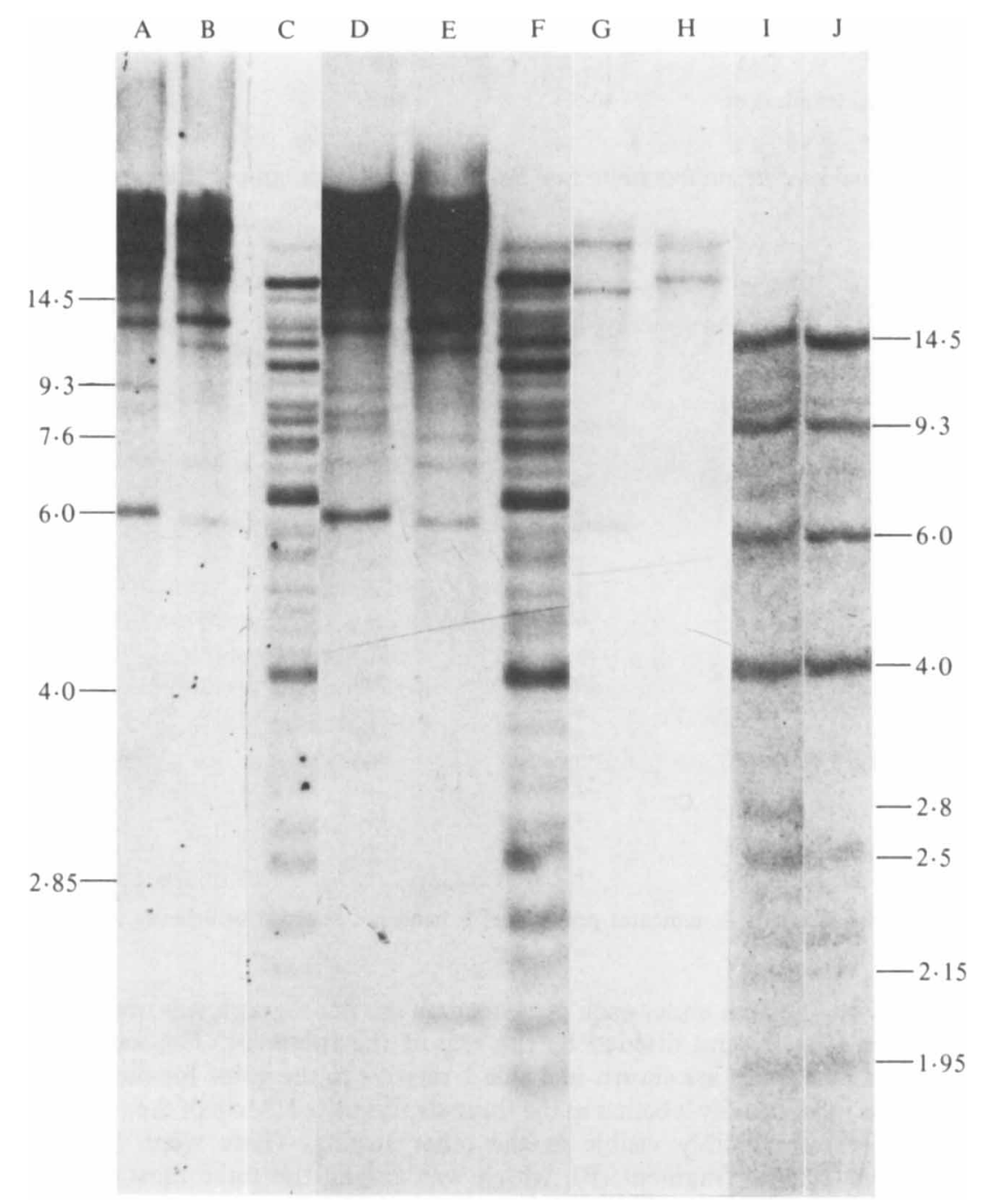

Fig. 1. Fluorographs of terminus DNA labelled for $2.5 \mathrm{~min}$. Lanes A, B and C, $168 \mathrm{trpC}$ digested with $B a m$ HI, Sall and EcoRI, respectively; D, E and F, 168 trpC2 Thy ${ }^{-}$digested with BamHI SalI and EcoRI, respectively; G and H, CU1050 digested with BamHI and SalI, respectively; I, 168 trp C2 Thy ${ }^{-}$ digested with EcoRI; J, CU1050 digested with EcoRI; Numbers are sizes in kb: left-hand side, tracks $\mathrm{A}-\mathrm{H}$; right-hand side, tracks $\mathrm{I}$ and $\mathrm{J}$. 
Table 1. Relative specific radioactivities of EcoRI fragments labelled in $2.5 \mathrm{~min}$

\begin{tabular}{|c|c|c|c|c|}
\hline & \multirow[b]{2}{*}{ Size (kb) } & \multicolumn{3}{|c|}{$\begin{array}{l}\text { Specific radioactivity } \\
\text { (relative units) }\end{array}$} \\
\hline & & $168 \mathrm{trpC2}$ & $168 \operatorname{trp} C 2 \mathrm{Thy}^{-}$ & CU1050 \\
\hline A & $4 \cdot 0$ & 100 & 100 & 100 \\
\hline B & 2.85 & 76 & 64 & 0 \\
\hline C & 6.0 & 67 & 67 & 53 \\
\hline D & 14.5 & 45 & 36 & 35 \\
\hline $\mathrm{E}$ & $9 \cdot 3$ & 36 & 57 & 30 \\
\hline $\mathrm{F}$ & $2 \cdot 32$ & 33 & 51 & 14 \\
\hline G & 2.5 & 32 & 50 & 56 \\
\hline H & $10 \cdot 3$ & 28 & 43 & 11 \\
\hline I & 7.6 & 27 & 28 & 0 \\
\hline $\mathbf{J}$ & $7 \cdot 1$ & 27 & 36 & 12 \\
\hline K & 1.95 & 20 & 51 & 28 \\
\hline L & $8 \cdot 3$ & 19 & 35 & 0 \\
\hline $\mathbf{M}$ & $2 \cdot 15$ & 14 & 28 & 66 \\
\hline N & 1.65 & 12 & 22 & 86 \\
\hline \multicolumn{2}{|c|}{ Total length (kb) } & 80.5 & $80 \cdot 5$ & $61 \cdot 8$ \\
\hline
\end{tabular}

Table 2. Relative specific radioactivities of BamHI and Sall fragments labelled in $2.5 \mathrm{~min}$

\begin{tabular}{|c|c|c|c|c|}
\hline & \multirow[b]{2}{*}{ Size (kb) } & \multicolumn{3}{|c|}{$\begin{array}{l}\text { Specific radioactivity } \\
\text { (relative units) }\end{array}$} \\
\hline & & $168 \operatorname{trp} C 2$ & $168 \operatorname{trp} C 2 \mathrm{Thy}^{-}$ & CU1050 \\
\hline \multicolumn{5}{|c|}{ BamHI } \\
\hline A & $14 \cdot 3$ & - & - & 100 \\
\hline B & $18 \cdot 3$ & 100 & 100 & - \\
\hline $\mathrm{C}$ & 25.0 & 76 & 67 & 73 \\
\hline $\mathrm{D}$ & 5.65 & 66 & 63 & 73 \\
\hline $\mathrm{E}$ & $15 \cdot 2$ & 62 & + & - \\
\hline $\mathrm{F}$ & $10 \cdot 8$ & 48 & 55 & - \\
\hline G & $40 \cdot 0$ & 23 & 45 & - \\
\hline $\mathbf{H}$ & 1.65 & + & + & + \\
\hline I & $12 \cdot 3$ & + & + & - \\
\hline \multicolumn{5}{|l|}{ Sall } \\
\hline A & 15.8 & 100 & 100 & 100 \\
\hline B & 23 & + & + & 86 \\
\hline $\mathrm{C}$ & 25 & 89 & 89 & 49 \\
\hline D & $11 \cdot 3$ & 75 & 90 & - \\
\hline $\mathrm{E}$ & 14.5 & + & + & - \\
\hline $\mathrm{F}$ & 10 & + & + & - \\
\hline G & $5 \cdot 58$ & + & + & - \\
\hline $\mathrm{H}$ & $2 \cdot 25$ & + & + & - \\
\hline
\end{tabular}

- Indicates absence of band; + indicates presence of a band not resolved sufficiently clearly to measure density of image.

specific radioactivity, the area under each peak seen on the fluorograph was obtained from the densitometer trace (Fig. 2) and divided by the size of the fragment. The values for EcoRI fragments labelled in $2.5 \mathrm{~min}$ are shown in Table 1 relative to the value for the $4 \mathrm{~kb}$ fragment which is clearly the most heavily labelled in the three strains tested. Most of the 14 bands seen in the wild-type were reproducibly visible in the other strains. There were, however, some differences. Thus a $2.85 \mathrm{~kb}$ fragment $(B)$, which was among the three most highly labelled fragments in the SP $\beta^{+}$strains was absent from the SP $\beta^{-}$strain. Fragments I and $L$, which were amongst the minor bands in $168 \operatorname{trpC} 2$ were absent from the SP $\beta^{-}$strain. Fragments $\mathrm{G}, \mathrm{M}$ and $\mathrm{N}$ appeared to be more prominent in the SP $\beta^{-}$strain than in the SP $\beta^{+}$strains. However, there was clearly a fundamental similarity between the three strains examined.

Using enzymes that cut $B$. subtilis DNA less frequently, the similarity between the labelling 


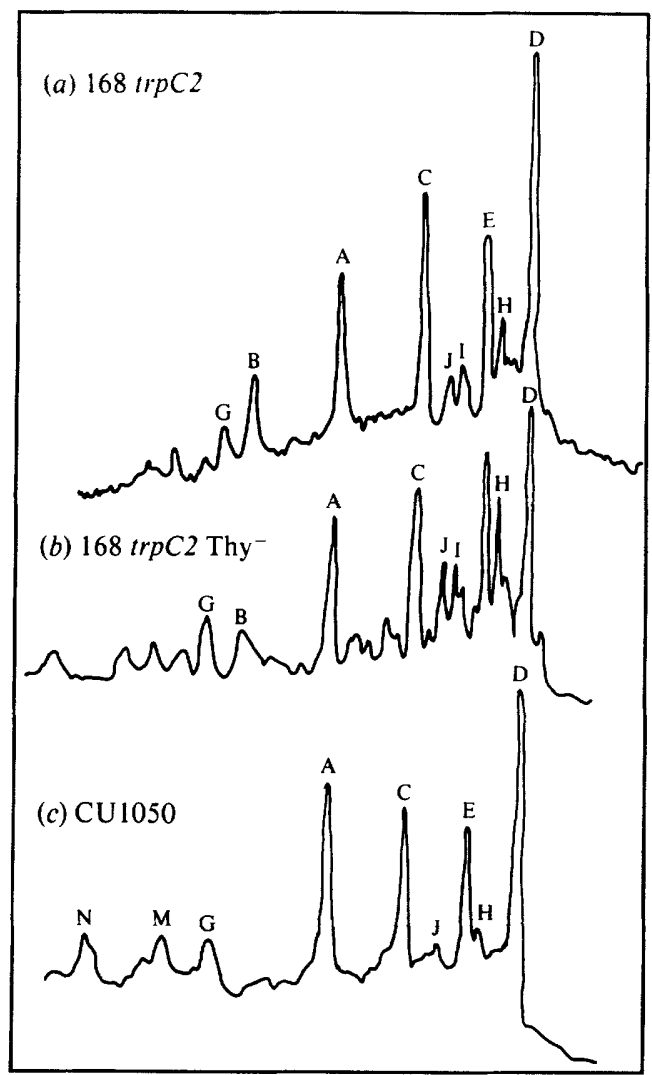

Fig. 2. Densitometer traces from fluorographs of terminus-labelled DNA digested with EcoRI. (a) 168 $\operatorname{trpC2} ;\left(\right.$ b) 168 trpC2 Thy $^{-} ;(c)$ CU1050.

patterns was less apparent. The BamHI fragment with the highest specific activity was $14.3 \mathrm{~kb}$ (A) in CU1050 and $18.3 \mathrm{~kb}$ (B) in the other two strains. BamHI fragments C and D were present in all three strains but the minor fragments $F$ and $G$ were not seen in CU1050. As the EcoRI fragments from the three strains were similar, fragment $A$ was probably homologous to fragment $B$ and probably contained a deletion or rearrangement.

All three strains gave $16 \mathrm{~kb}$ (A) and $25 \mathrm{~kb}$ (C) Sall fragments when labelled for $2.5 \mathrm{~min}$. In addition to these CU1050 gave a $23 \mathrm{~kb}$ band (B) and the other two strains gave an $11.3 \mathrm{~kb}$ band (D). The sum of the lengths of the restriction fragments labelled in 2.5 min was about $80 \mathrm{~kb}$ in the $\operatorname{SP} \beta^{+}$strains and about $62 \mathrm{~kb}$ in CU1050 $\left(\mathrm{SB} \beta^{-}\right)$. DNA replication probably occurs at a slower rate in the SP $\beta^{-}$strain.

\section{Identification of clones}

Direct methods of screening clone banks (Benton \& Davis, 1977) were impractical with a probe of such low specific activity as ${ }^{3} \mathrm{H}$-terminus-labelled DNA. However, using the threedimensional matrix described in Methods, a substantial number of clones were rapidly identified. These were characterized by restriction analysis. The presence of fragments in common between different phages was noted and from this information, linear maps were constructed. The terminal $E c o$ RI fragments from each group were used, after nick-translation, to identify further clones either by screening the three-dimensional bank or by plaque hybridization. The EcoRI, BamHI and SaII restriction maps of the phage isolated by this procedure are illustrated in Fig. 3. A variety of tests were used to establish that the fragments obtained in each clone were contiguous in the chromosome (unpublished observations). Several clones were found in which non-contiguous fragments had presumably been ligated together during construction of the bank; these have not been included. 


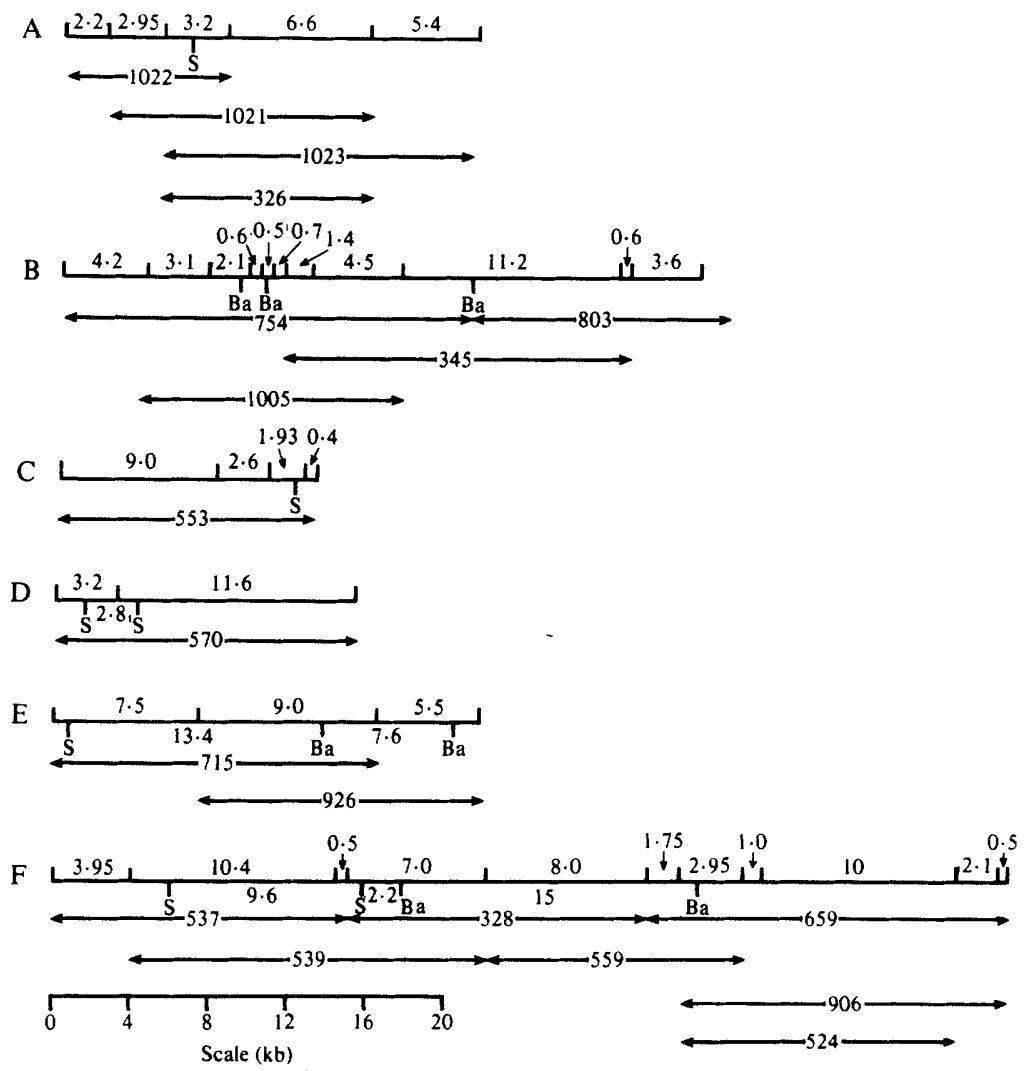

Fig. 3. Restriction maps of Charon $4 \mathrm{~A}$ clones containing sequences from the terminus region. A-F represent composite restriction maps of groups of clones that contain sequences that overlap. EcoRI fragments (sizes in $\mathrm{kb}$ ) are shown above the line and $B a m H I(B a)$ and $S a l I(S)$ fragments are shown below the line. Clones containing parts of these sequences are represented by arrows below the maps.

To confirm that the DNA present in the clones was from the terminus region, it was immobilized on nitrocellulose and hybridized quantitatively with two kinds of probe. These were ${ }^{3} \mathrm{H}$-terminus-labelled DNA (labelled for $10 \mathrm{~min}$ ) and ${ }^{32} \mathrm{P}$-labelled DNA of a $B$. subtilis strain (CU1695) which contains a large deletion extending from SP $\beta$ to the right of gltA. The amount of hybridization was corrected for any possible variation in the amount of cloned DNA on the filters by using a parallel set of filters which were incubated with ${ }^{32} \mathrm{P}$-labelled phage $\lambda$. This hybridizes with a substantial part of the vector DNA and therefore estimates the amount of bound DNA. The extent of hybridization per unit of cloned DNA was expressed per kb of insert (determined from the EcoRI restriction pattern).

All the groups of clones shown in Fig. 3 hybridized with terminus-labelled DNA (Table 3). The highest rate of hybrid formation per $\mu \mathrm{g}$ of cloned DNA, per kb, was with $\phi 553$ (group C) with lower rates in descending order $\mathrm{A}, \mathrm{D}, \mathrm{E}, \mathrm{B}$ and $\mathrm{F}(56,35,28,11$ and $5 \%$, respectively). Within any one group there was a comparable specific radioactivity in all the members of a group.

Hybridization with CU1695 DNA clearly differentiates between groups A-E and group F. The amount of hybrid formed in groups $A, B, D$ and $E$ was about $2 \%$ of the level seen with group F.

A slightly higher level of hybridization was found with $\phi 553$. This is probably explained by the presence of another region $(6.6 \mathrm{~kb})$ in CU1695 which has weak homology with $\phi 553$ (M. J. Monteiro, unpublished observations). This indicates that the majority of the clones obtained contain DNA from the region defined by the CU1695 deletion. None of the clones contain SP $\beta$ fragments (unpublished observations). 
Table 3. Hybridization of Charon $4 A$ clones with ${ }^{3} \mathrm{H}$-terminus labelled DNA and DNA of CU1695

\begin{tabular}{|c|c|c|c|c|c|c|}
\hline Group & Phage & $\begin{array}{c}\text { Size of } \\
\text { insert } \\
\text { (kb) }\end{array}$ & $\begin{array}{c}{ }^{3} \mathrm{H}-\text { Terminus } \\
\text { (c.p.m. per kb)* }\end{array}$ & Average & $\begin{array}{l}\text { Percentage of } \\
\text { maximum }\end{array}$ & $\begin{array}{l}\text { 32P-Labelled } \\
\text { CU1695 DNA }+\end{array}$ \\
\hline $\begin{array}{l}\text { A } \\
\text { A }\end{array}$ & $\begin{array}{r}326 \\
1006\end{array}$ & $\begin{array}{r}12 \cdot 0 \\
9 \cdot 8\end{array}$ & $\begin{array}{l}61.8 \\
71.7\end{array}$ & 66 & $56 \%$ & $\begin{array}{l}5 \\
8\end{array}$ \\
\hline B & 866 & 17.8 & 15.8 & & & 6 \\
\hline B & 703 & 11.8 & 11.8 & 13 & $11 \%$ & 4 \\
\hline B & 704 & $15 \cdot 4$ & 12.9 & & & 4 \\
\hline C & 553 & 13.9 & 117.0 & 117 & $100 \%$ & 27 \\
\hline D & 570 & $15 \cdot 4$ & $41 \cdot 4$ & 41 & $35 \%$ & 3 \\
\hline $\mathrm{E}$ & 964 & $14 \cdot 5$ & $29 \cdot 5$ & & & 2 \\
\hline $\mathrm{E}$ & 715 & $16 \cdot 5$ & 36.7 & 33 & $28 \%$ & 3 \\
\hline $\mathbf{F}$ & 537 & $14 \cdot 3$ & $7 \cdot 4$ & & & 197 \\
\hline$F$ & 688 & $10 \cdot 4$ & $9 \cdot 4$ & & & 218 \\
\hline $\mathbf{F}$ & 539 & $17 \cdot 8$ & 5.5 & & & 194 \\
\hline $\mathrm{F}$ & 328 & 17.2 & $5 \cdot 1$ & & & 224 \\
\hline $\mathrm{F}$ & 559 & 12.7 & 11.8 & 6.5 & $5 \%$ & 342 \\
\hline $\mathrm{F}$ & 659 & $15 \cdot 7$ & 2.9 & & & 134 \\
\hline $\mathbf{F}$ & 524 & 13.9 & 5.8 & & & 151 \\
\hline$F$ & 563 & 10.0 & 6.0 & & & 141 \\
\hline $\mathbf{F}$ & 906 & 16.5 & 4.6 & & & 155 \\
\hline
\end{tabular}

* $T / L K$; where $T={ }^{3} \mathrm{H}$-terminus-labelled DNA hybridized with phage DNA; $L={ }^{3} \mathrm{H} \lambda$ DNA hybridized with phage DNA; $K=$ size of insert in $\mathbf{k b}$.

$\dagger C / L K$; where $C={ }^{32}$ P-labelled CU1695 DNA hybridized with phage DNA; $L$ and $K$ as above.

Table 4. Sizes of BamHI and Sall fragments of $168 \mathrm{trpC2}$ DNA homologous with clones in groups $A-E$

Sizes (kb) of chromosomal fragments of $168 \operatorname{trpC2}$

\begin{tabular}{clll} 
Clone & \multicolumn{1}{c}{ SalI } & \multicolumn{1}{c}{ BamHI-SalI } \\
\cline { 2 - 4 } group & \multicolumn{1}{c}{ BamHI } & $13 \cdot 3,17$ & $13 \cdot 3$ \\
A & $35 \cdot 0$ & $35 \cdot 0$ & ND \\
B & $13 \cdot 0,16 \cdot 0$ & $22 \cdot 5$ & $15 \cdot 0, * 20 \cdot 0$ \\
C & $40 \cdot 0$ & $35-40,2 \cdot 8$ & $18 \cdot 2, * 3 \cdot 2,2 \cdot 8$ \\
D & $23 \cdot 0$ & $23 \cdot 5$ & $14 \cdot 0$ \\
E & $7 \cdot 6,23 \cdot 5$ &
\end{tabular}

ND, Not done.

* Substantially more heavily labelled than other bands.

\section{Blot hybridization of clones with BamHI and Sall fragments of 168 trpC2 DNA}

The relationship between the cloned sequences and the BamIII and SalI restriction fragments seen in fluorographs was investigated by blot hybridization (Southern, 1979). The sizes of the BamHI, Sall and BamHI-Sall doubly digested fragments hybridizing with cloned DNA are given in Table 4 . Where two or more clones constitute the group, the data were compiled from experiments with each probe. The data obtained have been used to determine the location of clones relative to the Weiss \& Wake (1983) map (see Discussion).

\section{Hybridization of $\phi 715$ with terminus-labelled DNA}

Comparison of the restriction maps of $\phi 715$ (group E) and the map of Weiss \& Wake (1983) indicated that the sequences in this clone originate from close to the terminus (see Discussion). An experiment was devised in which the replication of this region could be compared with that of SP $\beta$, which lies on the left-hand arm (Fig. 4).

DNA was prepared from spores obtained after pulse-labelling sporulating cells for various lengths of time. This was hybridized with either $\phi 715$ or SP $\beta$ DNA bound to nitrocellulose 


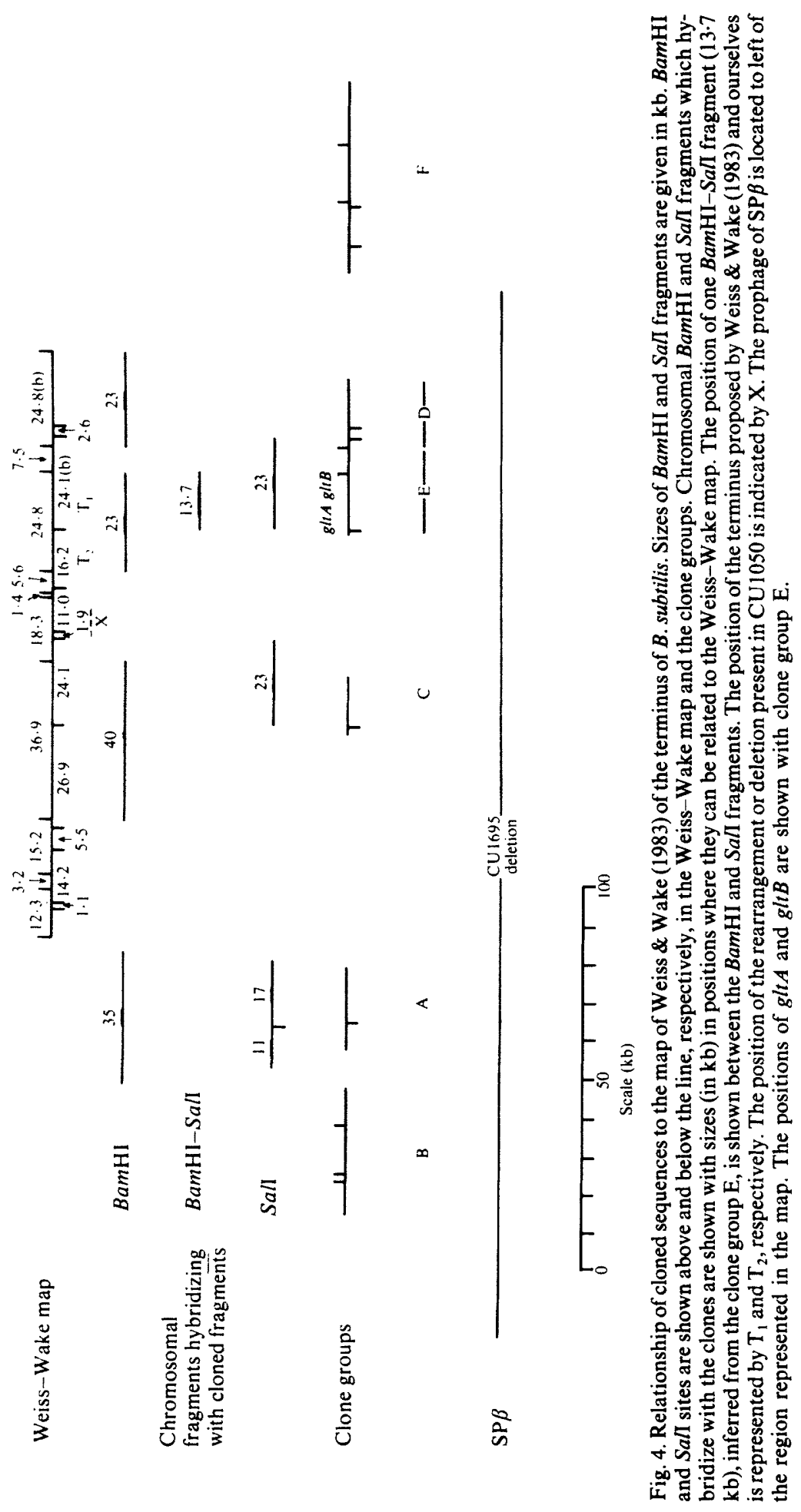




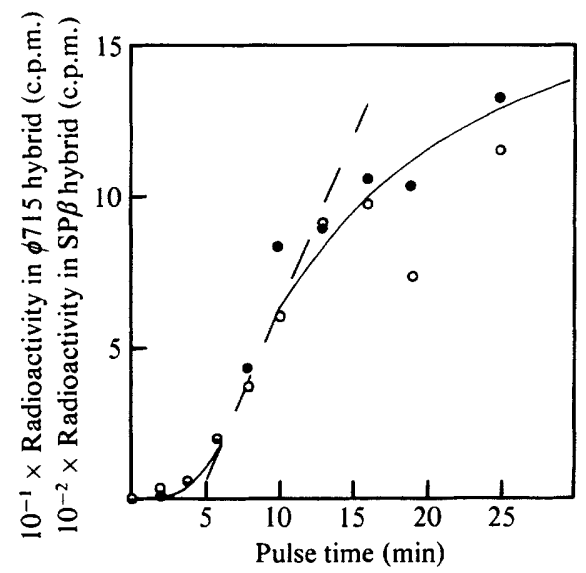

Fig. 5. Time of replication of $\phi 715$ and SP $\beta$ DNA. DNA $(1 \mu \mathrm{g})$ from spores pulse-labelled for the times shown was incubated with nitrocellulose filters containing $4 \mu \mathrm{g}$ denatured SP $\beta(O)$ or $\phi 715(O)$ DNA as described in Methods.

filters. The effect of pulse length on the radioactivity bound is illustrated in Fig. 5. The amount of hybrid formed using either phage starts to increase sharply after about $5 \mathrm{~min}$. If group $\mathrm{E}$ was to the left of the terminus (i.e. on the late replicating arm), the region would be heavily labelled in very short pulses. As it is not labelled for $5 \mathrm{~min}$, but is tightly linked to the most terminal fragment, it must be replicated from the right. The simultaneous labelling of the SP $\beta$ prophage and the $\phi 715$ region indicates that termination of the right-hand arm occurs as the SP $\beta$ prophage is replicated. The total radioactivity bound to $\operatorname{SP} \beta$ is approximately 10 times that bound to $\phi 715$ but $\operatorname{SP} \beta$ is 7.5 times greater in size than the insert in $\phi 715$.

\section{Association of genetic markers with cloned DNA}

The genetic map of the terminus region contains the markers $k a u A$, cit $K$, glt $B$, glt $A$, citB , and $g \ln A$ which may be considered sufficiently close to the terminus to merit investigation (Henner $\&$ Hoch, 1980). Suitable recipients were transformed with approximately $1 \mu \mathrm{g}$ purified DNA of the isolated clones. Clones containing $k a u A, \operatorname{cit} K, \operatorname{cit} B$ and $g \ln A$ were not identified. However $\phi 926$ and $\phi 715$ were positive for $g l t B 1$ and $g l t A 2$, while $\phi 715$ was positive for $g l t A 292$. Studies with isolated fragments indicated that the $9.0 \mathrm{~kb} E c o \mathrm{RI}$ fragment in group E corrected $g l t B$ and glt $A 2$ and the $7.5 \mathrm{~kb}$ fragment corrected glt $A 292$, and thus confirmed and extended the observations of Fisher \& Kane (1981).

\section{DISCUSSION}

The sensitivity of the terminus labelling technique provides an opportunity to determine with considerable precision whether the chromosomal terminus is merely the point at which replication forks meet or whether a specific sequence arrests replication forks. Weiss \& Wake (1983) have used this technique to show that there is a fixed terminus and that there is a $\leqslant 5 \mathrm{~min}$ difference in the time of termination of the right- and left-hand forks. According to the former model, the presence of a deletion in one arm of the chromosome would change the position of the terminus, or according to the latter would have no effect. The test used here was to compare the wild-type $B$. subtilis which is lysogenic for SP $\beta$ with strains which lack the $120 \mathrm{~kb}$ prophage. When the terminal region of the $B$. subtilis chromosome was labelled for $2.5 \mathrm{~min}$, only a small number of EcoRI restriction fragments with a total length of $80 \mathrm{~kb}$ were labelled and the patterns of the three strains examined were qualitatively very similar. Fragments of 4 and $6 \mathrm{~kb}$ had the highest specific activity in the three strains examined and furthermore, 11 out of 14 bands seen in the SP $\beta^{+}$strains were present in the SP $\beta^{-}$strain. As the total length of DNA labelled in 2.5 min was smaller than the $\mathrm{SP} \beta$ prophage, a substantial change in pattern in SP $\beta^{-}$ 
strains would be expected if the chromosomal terminus was merely the point at which chromosomal forks meet. The close similarity of $\operatorname{SP} \beta^{+}$and $\operatorname{SP} \beta^{-}$strains suggests that there must be a specific stop sequence.

There were, however, differences in the restriction patterns of $\operatorname{SP} \beta^{+}$and $\operatorname{SP} \beta^{-}$strains. The absence of one major $2.8 \mathrm{~kb} E c o R I$ band from the SP $\beta^{-}$strain probably indicates that in addition to the deletion resulting from the loss of $\mathrm{SP} \beta$ there is another small rearrangement or deletion in the terminal region. Differences between the much larger SalI and BamHI restriction fragments were also observed but these differences were probably consequences of the deletion as the EcoRI patterns were so similar. Several minor EcoRI bands seen in the wild-type were missing from the SP $\beta^{-}$strain labelled for $2.5 \mathrm{~min}$, but as the rate of DNA replication was slightly reduced compared with the wild-type these were probably not labelled. No convincing differences between $168 \operatorname{trpC} 2$ and the $\mathrm{Thy}^{-}$strain have been demonstrated.

The relative specific radioactivities of the BamHI and Sall fragments observed in $168 \operatorname{trpC2}$ were consistent with the order of replication suggested in the map of Weiss \& Wake (1983). Our most radioactive $S a l l$ fragment, $A$, is $15.8 \mathrm{~kb}$ and is probably identical to the $16.2 \mathrm{~kb} S a / \mathrm{I}$ fragment that Weiss \& Wake (1983) consider to be the terminal fragment; our fragment D $(11.3 \mathrm{~kb})$ corresponds to their $11.0 \mathrm{~kb}$ fragment which is next to the $16.2 \mathrm{~kb}$ fragment. Our fragment $C(25 \mathrm{~kb})$ probably results from superimposition of the 26.9 and $24 \cdot 1$ (a) kb fragments. The order of BamHI fragments on the left-hand arm of the terminus shown by Weiss \& Wake (1983) is 24.8(a) (terminus), 5.6, 1.4, 18.3 and $36.9 \mathrm{~kb}$. Equivalents of all of these (C, D, H, B and $G$, respectively) were seen in our fluorographs of 2.5 min labelled DNA, although the order of labelling did not correspond exactly. However, this probably reflects the limitation of the method of determining specific activity.

The restriction fragments labelled in the wild-type in $2.5 \mathrm{~min}$, which are absent from CU1050 are the $11.3 \mathrm{~kb} S a / \mathrm{I}$ and $18.3 \mathrm{~kb} \mathrm{BamHI}$ fragments. This indicates that the rearrangement or deletion lies in the region marked $\mathbf{X}$ in Fig. 3.

Independently of Weiss \& Wake (1983), we have been constructing a map of the terminus using fragments of DNA cloned in Charon 4A. The probe used to screen for these clones was prepared from spores of CU1050, in order to eliminate SP $\beta$ clones from our survey. Pulses of 10 min were employed to ensure that the fast replicating arm would be labelled more strongly than with shorter pulse periods.

Five of the six groups of clones come from a very restricted region of the chromosome, defined by the deletion in CU1695 that extends from SP $\beta$ to the right of gltA (Zahler et al., 1982). The position of groups $C, D$ and $E$ were identified satisfactorily in the Weiss-Wake map by means of the BamHI and SalI sites (Fig. 3). Blot hybridization experiments confirmed that the chromosomal fragments generated by BamHI, SalI or BamHI-Sall double digestions were of the size indicated by the map of Weiss \& Wake (1983) (Table 4 and Fig. 3). This information indicated that groups $\mathrm{D}$ and $\mathrm{E}$ were almost exactly contiguous, but unfortunately we were unable to obtain a clone from the $\lambda$ bank which overlapped the two groups. However, using an independent approach we have cloned, in a plasmid, a chromosomal fragment that does overlap the two groups (M. G. Sargent, unpublished observation).

Group C contained only one $S a l l$ site but could be assigned to the position shown in Fig. 3 on the basis of the BamHI (40 kb), Sall (23 kb) and BamHI-SalI (20 and $15 \mathrm{~kb})$ fragments to which it hybridized. The $15 \mathrm{~kb} \mathrm{BamHI-Sall}$ fragment observed was considerably more heavily labelled than the $20 \mathrm{~kb}$ fragment and therefore indicates the orientation of the clone.

Sequences like groups A and B are quite definitely not present in the Weiss-Wake map and not present in CU1695. Group A has a substantial specific activity of hybridization with terminus-labelled DNA and probably originates from a region just to the left of the Weiss-Wake region. Group $B$ we more tentatively assign to the same region.

The total length of cloned DNA from the region defined by the CU1695 deletion is now more than $150 \mathrm{~kb}$ and substantially greater than the distance suggested by analysis of the available transduction data (Weiss \& Wake, 1983).

The group F contained a $48 \mathrm{~kb}$ length of DNA that hybridized with CU1695 and was weakly labelled by the $10 \mathrm{~min}$ terminus probe. It probably is located to the right of the Weiss-Wake 
region on the early terminating arm of the chromosome. Direct evidence for this has been obtained by genetic mapping experiments. Non-replicative plasmids which contain the terminal EcoRI fragment of group $\mathrm{F}$ have been inserted into the chromosome by homology and the introduced chloramphenicol resistance mapped by transformation. The $3.95 \mathrm{~kb}$ fragment of $\phi 537$ was linked to $g l t A$ while the $2 \cdot 1 \mathrm{~kb}$ fragment of $\phi 906$ was not. This indicates that there is only a small gap between group $\mathrm{F}$ and the gltA region (M. G. Sargent, unpublished observations).

The genetic evidence for the location of the terminus of replication rests on now classical density transfer studies which placed the terminus close to the markers citK and gltA (Harford, 1975 ). More recently, it has been suggested that the terminus lies to the right of gltA (O'Sullivan \& Anagnostopoulos, 1983). Using merodiploid strains in which the length of the left-hand side was increased by a large duplication, these authors showed that replication of $g l t A$ was delayed and that this marker was still the last to replicate. If the terminus had been between glt $A$ and SP $\beta$ for example, glt $A$ would have been replicated by the right-hand fork at the normal scheduled time.

The gltA292 mutation was corrected by the $7.5 \mathrm{~kb}$ EcoRI fragment of $\phi 715$, and gltA2 and glt $B 1$ corrected by the $9 \mathrm{~kb}$ fragment of $\phi 715$. All of these are presumably on the $13.7 \mathrm{~kb}$ Bam HI-Sall fragment ( $\mathrm{T}_{1}$ in Fig. 4), thus supporting the tentative suggestion of Weiss \& Wake (1983). However, almost all of this fragment lies to the right of the terminus indicated by their map, and therefore contradicts the conclusion of O'Sullivan \& Anagnostopoulos (1982) which suggests that glt $A$ is to the left of the terminus. EcoRI fragments of close to 7.5 and $9.0 \mathrm{~kb}$ are present in 2.5 min terminus-labelled DNA, but these are unlikely to be the fragments in $\phi 715$, as the kinetics of labelling indicate that the region does not become radioactive unless pulselabelled for $5 \mathrm{~min}$ or more. Even in a $10 \mathrm{~min}$ labelling period, the specific activity determined by DNA-DNA hybridization (Table 3) of this region was only one-third of that of $\phi 553$. This observation suggests that a more accurate position for the terminus is slightly to the left of $T_{1}$ (Fig. 4), suggested by Weiss \& Wake (1983), at $\mathrm{T}_{2}$. The data of O'Sullivan \& Anagnostopoulos (1982) may be explained by suggesting that the region around gltA is inverted so that $g l t A$ is on the late terminating arm of the chromosome.

The possibility of an attachment of the terminal region of the chromosome to the cell membrane has been widely discussed. We have shown previously that the ilvA-ilvD region is enormously enriched in a membrane fraction while the terminal region marker gltA is not (Sargent \& Bennett, 1982). Attempts to demonstrate enrichments of terminally labelled DNA in the membrane fraction indicate that only a small portion of the terminal region can be membrane-bound and this part is probably a substantial distance from the terminus (Sargent \& Bennett, 1982). None of the cloned fragments described above were membrane-bound and furthermore membrane-bound DNA in CU1695 had an identical composition to membranebound DNA in the wild-type (M. G. Sargent, unpublished observations). Although there may be membrane-bound regions present in the uncloned regions, the major membrane binding site in the late replicating part of the chromosome appears to be at $i l v A-i l v D$, which is at least $240 \mathrm{~kb}$ from gltA.

There is no obvious explanation of the apparently paradoxical findings of the fixed nature of the terminus on the one hand and its dispensibility in CU1695 although, presumably, it indicates that alternative mechanisms of termination must be present in the bacterial cell. Unfortunately, we are unable to determine the sequence used in CU1695 as this strain is unable to sporulate.

One of us (M.J.M.) gratefully acknowledges the receipt of an MRC postgraduate scholarship.

\section{REFERENCES}

Adams, R. T. \& Wake, R. G. (1980). Highly specific labelling of the terminus of the Bacillus subtilis chromosome. Journal of Bacteriology 143, 1036-1038. Benton, W. D. \& Davis, R. W. (1977). Screening lambda gt. recombinant clones by hybridisation to single plaques in situ. Science 196, 180-182.
Bouché, J. P. (1982). Physical map of a $470 \times 10^{3}$ base pair region flanking the terminus of DNA replication in the Escherichia coli $\mathrm{K} 12$ genome. Journal of Molecular Biology 154, 9-20.

Bouchí, J. P., Gelugne, J. P., Louarn, J., Louarn, J. M. \& KAISER, K. (1982). Relationships between 
the physical and genetic maps of a $470 \times 10^{3}$ base pair region around the terminus of Escherichia coli K12. Journal of Molecular Biology 154, 21-32.

Callister, H. \& Wake, R. G. (1974). Completed chromosomes in thymine requiring Bacillus subtilis spores. Journal of Bacteriology 120, 579-582.

DAVERN, C. (1979). Replication of the prokaryotic chromosome with emphasis on the bacterial chromosome replication in relation to the cell cycle. In Cell Biology, vol. 2, pp. 131-169. Edited by D. M. Prescott and L. Goldstein. New York: Academic Press.

Deshpande, K. L. \& Kan, J. F. (1980). Glutamate synthase from Bacillus subtilis: in vitro reconstitution of an active amido-transferase. Biochemical and Biophysical Research Communications 93, 308-314.

DeWet, J. R., Daniels, D. L., Schroeder, J. L., Williams, B. G., DenNISTON-ThOMPSON, K., MoORE, D. D. \& BlattNer, F. R. (1980). Restriction maps for twenty-one Charon vector phages. Journal of Virology 33, 401-410.

Dretzen, G., Bellard, M., Sassone-Corsi, P. \& Chambon, P. (1981). A reliable method for the recovery of DNA fragments from agarose and acrylamide gels. Analytical Biochemistry 112, 295298.

Ferrari, E., Henner, D. J. \& Hoch, J. A. (1981). Isolation of Bacillus subtilis genes from a Charon 4A library. Journal of Bacteriology 146, 430-432.

Fisher, R. S. \& KANE, J. F. (1981). Regulation of glutamate synthase in Bacillus subtilis. Proceedings of the CETUS Conference on Molecular Cloning and Gene Regulation in Bacilli, Stanford University.

Germino, J. \& BASTIA, D. (1981). Termination of DNA replication in vitro at a sequence specific replication terminus. Cell $23,681-687$.

HARFORD, N. (1975). Bidirectional chromosome replication in Bacillus subtilis. Journal of Bacteriology 121, 835-847.

Henner, D. J. \& HoCH, J. A. (1980). The Bacillus subtilis chromosome. Microbiological Reviews 44, 5782.

Jeffreys, A. L. \& Flavell, R. A. (1977). A physical map of the DNA regions flanking the rabbit $\beta$-globin genes. Cell 12, 429-439.

Kuempel, P. L., DuerR, S. A. \& Seeley, N. R. (1977). Terminus region of the chromosome in Escherichia coli inhibits replication forks. Proceedings of the National Academy of Sciences of the United States of America 74, 3927-3931.

LASKEY, R. A. (1980). The use of intensifying screens or organic scintillators for visualising radioactive molecules resolved by gel electrophoresis. Methods in Enzymology 65, 363-370.

Louarn, J., Patte, J. \& Louarn, J. M. (1977). Evidence for a fixed termination site of chromosome replication in Escherichia coli K12. Journal of Molecular Biology 155, 295-314.
O'Sullivan, M. A. \& Anagnostopoulos, C. (1982). Replication terminus of the Bacillus subtilis chromosome. Journal of Bacteriology 151, 135-143.

REYSSET, G. (1981). New class of Bacillus subtilis glutamine requiring mutants. Journal of Bacteriology 148, 653-658.

Rosenthal, R., Toye, P. A., Korman, R. Z. \& ZAHLER, S. A. (1979). The prophage of $\operatorname{SP} \beta_{\mathrm{c} 2} \mathrm{CitK}{ }_{1}$. A defective specialised transducing phage of $B$. subtilis. Genetics 92, 721-739.

SARGENT, M. G. (1980a). Chromosome replication in sporulating cells of Bacillus subtilis. Journal of Bacteriology 142, 491-498.

SARGENT, M. G. $(1980 b)$. Specific labelling of the Bacillus subtilis terminus. Journal of Bacteriology 143, 1033-1035.

SARGENT, M. G. $(1980 c)$. A procedure for isolating high quality DNA from spores of Bacillus subtilis. Journal of General Microbiology 116, 511-514.

SARGENT, M. G. \& BeNNETT, M. F. (1982). Attachment of the chromosomal terminus of Bacillus subtilis to a fast sedimenting particle. Journal of Bacteriology 150, 623-632.

Sargent, M. G. \& Monteiro, M. J. (1982). Characterization of the chromosomal terminus of $B$. subtilis and its attachment to the cell membrane. In Molecular Cloning and Gene Regulation in Bacilli, pp. 181-195. Edited by A. T. Ganesan, S. Chang \& J. A. Hoch. New York: Academic Press.

Sargent, M. G., BennetT, M. S. \& Burdett, I. D. J. (1983). Identification of specific restriction fragments associated with a membrane sub-particle from Bacillus subtilis. Journal of Bacteriology 154, 1389 1396.

SOUTHERN, E. (1979). Gel electrophoresis of restriction fragments. Methods in Enzymology 68, 152-176.

Warner, F. G., Kotos, G. A., Romano, M. P. \& HEMPHILL, H. E. (1977). Characterisation of SP $\beta$, a temperate phage of Bacillus subtilis M168. Canadian Journal of Microbiology 129, 556-558.

WEISS, A. S. \& WAKE, R. G. (1983). Restriction map of DNA spanning the replication terminus of the Bacillus subtilis chromosome. Journal of Molecular Biology 171, 119-137.

Weiss, A. S., Hariharan, I. K. \& Wake, R. G. (1981). Analysis of the terminus region of the Bacillus subtilis chromosome. Nature, London 293, 673-675

Weiss, A. S., Hariharan, I. K., Adams, R. T.\& WaKe, R. G. (1982). Characterisation of the terminus region of the $B$. subtilis chromosome. In Molecular Cloning and Gene Regulation in Bacilli, pp. 197-210. Edited by A. T. Ganesan, S. Chang \& J. A. Hoch. New York: Academic Press.

ZAHLER, S. A. (1982). Specialised transduction in Bacillus subtilis. In The Molecular Biology of the Bacilli, pp. 269-305. Edited by D. A. Dubnau. New York: Academic Press. 